DOI: https://doi.org/10.32838/2523-4803/69-6-33

УДК 38.43:631.11

\title{
Нісходовська О.Ю.
}

кандидат економічних наук, асистент кафедри економіки, підприємництва, торгівлі та біржової діяльності,

Подільський державний аграрно-технічний університет

\section{Niskhodovska Olena}

State Agrarian and Engineering University in Podilya

\section{ЗАРУБІЖНИЙ ДОСВІД УПРАВЛІННЯ ІННОВАЦІЙНИМ ПОТЕНЦАЛОМ ЕКОНОМІКИ}

У статті розглянуто та проаналізовано теоретичні аспекти інноваційної політики промислово розвинених країн. На їх прикладі проаналізовано зарубіжний досвід державного регулювання інновачійної діяльності, висвітлено найбільш дієві інструменти стимулювання інновачійної діяльності за кордоном, узагальнено рейтинг крайн світу за фінансуванням НДДКР та за індексом глобального економічного розвитку. Визначено особливості реалізації інноваційної політики крайн. 3 'ясовано, щцо немає єдиного універсального інструменту стимулювання економіки, тому щзо кожна краӥна має свої власні методи управління. Обгрунтовано доиільність використання інструментів в умовах украӥнської економіки для стимулювання інновачійної діяльності підприємств, організацій та установ. Серед основних чинників сприйнятливості до нововведень виділено інноваційний потенціал організаиічй чи підприємств.

Ключові слова: інноваџійна діяльність, інноваційна політика, інноваційний потенціал, глобалізаизія економіки, інноваційні структури, інноваційні процеси.

Постановка проблеми. 3 початку XXI ст. 3 кожним роком все більше і більше посилюється процес синхронізації економічного розвитку з досягненнями науки, техніки та тенденціями впровадження нових технологій у будь-яку сферу діяльності людства. Байдужість, необізнаність чи малоефективність здійснення структурної перебудови діяльності будь-якого суб'єкта глобальної економічної системи відповідно до вимог нового технологічного укладу не тільки обертається втратою перспектив розвитку, але й призводить до повної економічної деградації. А темпи розвитку інновацій роблять цей процес ще оперативнішм.

Знайомий всім термін «потенціал» (лат. potentia сила, потужність) означає здатність і готовність будьякої організації чи підприємства здійснювати реалізацію інноваційного процесу. 
Вдалий підхід до системи управління інноваційним потенціалом підприємства чи організації вимагає створення відповідного організаційно-економічного механізму забезпечення процесу управління цим потенціалом, головними складовими частинами якого є ціль, принципи, функції та методи управління.

Динамічний характер інноваційної діяльності може пояснюватись еволюційними закономірностями, однак повністю від них не залежить, адже інноваціями часто можуть ставати об'єкти радикального характеру, які за своєю природою є первинною ланкою нової еволюційної системи. Саме тому в практиці побудови інноваційних економік країн світу слід розрізняти еволюційний та революційний підходи.

Аналіз останніх досліджень і публікацій. 3 огляду на актуальність вибраної проблематики, варто відзначити, що іï дослідженням займалися чимало вітчизняних та закордонних науковців, таких як: О.В. Ареф’єв, О.В. Коренков, А.Е. Воронков, А.П. Гречан, А.В. Гриньов, С.М. Ілляшенко, О.С. Федонін, I.M. Рєпін, О.І. Олексюк, Н.I. Чухрай, М. Портер, С. Прігожін, Б. Санто, Р. Солоу, Б. Твісса, М. ТуганБарановський, Р. Фатхутдінов, К. Фрімен, Д. Черваньов, Й.-А. Шумпетер та ін. Проте загалом проблема оцінки інноваційного потенціалу як найбільш ефективного ресурсу розвитку регіонів залишається досі відкритою.

Мета статті полягає у дослідженні досвіду економічно розвинених країн щодо формування та реалізації державної інноваційної економіки, а також у розгляді на їх основі напрямів активізації інноваційного потенціалу.

Виклад основного матеріалу дослідження. У загальному розумінні інноваційний потенціал підприємства являє собою сукупність усіх наявних та прихованих ресурсів і можливостей підприємства для розроблення та впровадження різного роду нововведень, що формуються та реалізуються під впливом циклічного розвитку макросередовища. Інноваційний потенціал характеризують такими рисами:

- визначається реальними (реалізованими та нереалізованими) можливостями підприємства в сфері інноваційної діяльності;

- наявність ресурсів не охоплює вміння розпоряджатися ними, процвітання та зростання приходять тільки до такого бізнесу, який систематично знаходить і розробляє свій інноваційний потенціал. Тому інноваційний потенціал підприємства суттєво залежить не лише від ресурсної забезпеченості, але й від спроможності менеджерів їх раціонально використовувати у фактичних умовах господарювання.

Для найбільш ефективного використання інноваційних можливостей підприємства та максимізації результатів роботи важливе значення має розуміння усіх доступних шляхів нарощування потенціалу підприємства, а також здатність адекватно оцінювати вплив внутрішніх і зовнішніх факторів на процес формування інноваційного потенціалу.

Сучасні євроінтеграційні прагнення України мають забезпечуватися реальними соціально-економічними перетвореннями, в яких фактор інновацій має виступати безальтернативним. Насамперед на початку ефективного процесу формування єдиного універсального підходу до організації інноваційної економіки будь-якої країни має пріоритет дослідження вже наявного досвіду в цій сфері країн світу, а для України - досвіду країн СС.

Складність побудови й розвитку інноваційної економіки на рівні держави зумовлюється високим рівнем диверсифікації сфер упровадження інновацій і постійним попитом, що стрімко підвищує вартість таких змін. Таким чином, інноваційний потенціал є складною, динамічною, ієрархічною і стохастичною системою.

Для багатьох розвинених країн характерний комплексний підхід до регулювання інноваційної діяльності, що грунтується на застосовуванні методів як прямого впливу, так і непрямого стимулювання. Інноваційне середовище в різних країнах неоднакове, тому що кожна країна перебуває на своєму рівні розвитку, рівні технологій, рівні освіти, рівні інноваційної активності тощо. Це сукупність інших факторів, що зумовлюють ситуацію, коли інструменти інноваційної політики і механізми їх використання можуть ефективно діяти в одній країні, а в інших країнах бути зовсім непридатними, недієвими, неефективними. Тим не менше, прогресивний досвід передових країн важливий для вивчення та творчого застосування на етапі необхідності прискорення економічного зростання країни з поступовим відходом від траєкторії залежного розвитку. Тому зіставлення досвіду держав, що входять у технологічне ядро світового розвитку, - США, Японії, Великобританії, Свропейського Союзу (в останньому до такого типу держав насамперед належать Німеччина та Франція), буде цікавим і корисним для України [4, с. 203].

Отже, розглянемо інструменти стимулювання інноваційної діяльності країн, які посідають лідируючі місця за індексом глобальної конкурентоспроможності (The Global Competitiveness Index). Індекс глобальної конкурентоспроможності складається Всесвітнім економічним форумом для визначення рейтингу країн за показником економічної конкурентоспроможності та містить 114 показників для 140 країн, при цьому враховуються як статистичні дані, так і опитування керівників бізнесу [4; 20] для різнобічності оцінок. Україна ніколи не займала лідируючих позицій у цьому рейтингу, що є спонукальним фактором подальшого розвитку. Десятка країн, які займають найвищі місця за цим індексом, у динаміці 2012-2018 рр. наведена в табл. 1. Також представлена й позиція України.

Як і раніше, без сумніву, рейтинг очолила Швейцарія. До десятки найконкурентоспроможніших країн світу увійшли США, Сінгапур, Нідерланди, Німеччина, Гонконг, Швеція, Великобританія, Японія та Фінляндія. США та Японія - лідери за рівнем розвитку інновацій і за фінансуванням науково-дослідних та дослідно-конструкторських робіт (НДДКР), тому вони - найбільші конкуренти для підприємств Західної Європи, які змушені активізувати узгодження й об’єднання НДДКР, планувати та реалізовувати спільні 
Рейтинг країн світу за індексом глобальної конкурентоспроможності

\begin{tabular}{|c|c|c|c|c|c|c|c|c|c|}
\hline № & $\begin{array}{c}\text { 2013-2014 } \\
\text { (148 країн) }\end{array}$ & № & $\begin{array}{c}\text { 2014-2015 } \\
\text { (144 країни) }\end{array}$ & № & $\begin{array}{c}\text { 2015-2016 } \\
\text { (140 країн) }\end{array}$ & № & $\begin{array}{c}\text { 2016-2017 } \\
\text { (138 країн) }\end{array}$ & № & $\begin{array}{c}\text { 2017-2018 } \\
\text { (137 країн) }\end{array}$ \\
\hline 1 & Швейцарія & 1 & Швейцарія & 1 & Швейцарія & 1 & Швейцарія & 1 & Швейцарія \\
\hline 2 & Сінгапур & 2 & США & 2 & Сінгапур & 2 & Сінгапур & 2 & США \\
\hline 3 & Фінляндія & 3 & Сінгапур & 3 & США & 3 & США & 3 & Сінгапур \\
\hline 4 & Німеччина & 4 & Нідерланди & 4 & Німеччина & 4 & Німеччина & 4 & Нідерланди \\
\hline 5 & США & 5 & Німеччина & 5 & Нідерланди & 5 & Нідерланди & 5 & Німеччина \\
\hline 6 & Швеція & 6 & Гонконг & 6 & Японія & 6 & Японія & 6 & Гонконг \\
\hline 7 & Гонконг & 7 & Швеція & 7 & Гонконг & 7 & Гонконг & 7 & Швеція \\
\hline 8 & Нідерланди & 8 & Велика Британія & 8 & Фінляндія & 8 & Фінляндія & 8 & Велика Британія \\
\hline 9 & Японія & 9 & Японія & 9 & Швеція & 9 & Швеція & 9 & Японія \\
\hline 10 & Велика Британія & 10 & Фінляндія & 10 & Велика Британія & 10 & Велика Британія & 10 & Фінляндія \\
\hline 84 & Україна & 76 & Україна & 79 & Україна & 85 & Україна & 81 & Україна \\
\hline
\end{tabular}

інвестиційні проекти і програми. Свропейський Союз використовує кілька інструментів інноваційної політики та залучення інвестицій для фінансування інноваційної діяльності. Серед них виділяють пряме державне фінансування, насамперед шляхом виділення грантів, кредитів, субсидій тощо; створення інфраструктури для інноваційної діяльності; податкові стимули, спеціальні схеми підтримки ризикового фінансування, надання державних гарантій [3, с. 16].

Рівень інвестицій в Україні та загальна продуктивність факторів виробництва, тобто ефективність використання робочої сили, капіталу та землі між секторами та підприємствами, залишаються низькими. Водночас середньостатистичний робітник у Німеччині за 17 днів виробляє стільки ж, скільки середньостатистичний робітник в Україні за один рік. Великі відмінності в низькому рівні випуску продукції на одного робітника порівняно з розвинутими країнами зумовлені як відставанням України в ефективності виробництва, так і меншою кількістю основного капіталу.

Протягом останнього десятиліття Україна досягла певного прогресу у подоланні розриву в ефективності, але країна залишається обмеженою у кількості основного капіталу через нестачу інвестицій, включаючи і прямі іноземні інвестиції.

Загальні підходи, а також інструменти реалізації інноваційної політики у різних країнах суттєво відрізняються. Так, у Португалії чи Іспанії наявні фіскальні стимули не залежать від розміру підприємств-отримувачів; натомість у Великобританії акцент зроблений на суб'єктах малого та середнього бізнесу. У країнах iз високим рівнем науково-технологічного розвитку (Швеція, Німеччина, Фінляндія) надають перевагу заходам прямої фінансової підтримки, що забезпечує можливість державі визначати, які технології або який сектор економіки потрібно розвивати насамперед. На відміну від опосередкованих методів стимулювання фінансова допомога має цільовий характер. Держава, а не ринок, визначає, коли додаткове стимулювання необхідно, а коли це не потрібно [3].

Сучасними формами організації інноваційного потенціалу держави виступають інноваційні банки, страхові фірми, біржі, служби менеджменту та маркетингу, реклами, інформаційні та сервісні організації, що здійснюють свою діяльність у науковій сфері також. Саме тому є потреба у дослідженні зарубіжного досвіду у сфері регулювання інноваційних процесів країн для майбутніх можливостей їх застосування в Україні.

А у майбутньому головна проблема України полягатиме не в тому, щоб досягти високого зростання наступного року або протягом кількох років, а скоріше в тому, щоби зробити економічне зростання швидшим, тривалішим та інклюзивнішим.

Висновок. Отже, у наступні десять років нові тенденції у розвитку інноваційної діяльності будуть визначальними факторами інноваційної політики. Для цього необхідно здійснити сукупність методів та заходів визначення та реалізації пріоритетних напрямів розвитку науки і техніки, перспективних елементів інноваційної діяльності, що забезпечить розвиток економічного прогресу загалом, підвищення рівня конкурентоспроможності національної економіки. Такий комплексний підхід до вдосконалення державного регулювання інноваційної діяльності з урахуванням дієвого зарубіжного досвіду дасть змогу очікувати тільки на позитивні результати.

\section{Список літератури:}

1. Авігдор Г., Архангельський В., Бойто Е. та ін. Інноваційна політика : європейський досвід та рекомендаиії для України. К.: Фенікс, 2015. 76 с.

2. Бошота Н.В., Шишола Д.В. Зарубіжний досвід державного регулювання інноваційної діяльності. Молодий вчений. 2016. № 9. С. 14-18.

3. Голляк Ю.Б. Інноваційні перетворення української економіки в контексті міжнародної конкуренції. Актуальні проблеми економіки. 2006. №. 7(61). С.43-55

4. Касьяненко В. Зарубіжний досвід управління інноваційним потенціалом економіки та можливості його використання в Україні. Маркетинг і менеджмент інновацій. No. 4.2011. С. 200-204. 
5. Лавриненко С.О. Теоретичні аспекти конкурентоспроможності сільськогосподарської продукції в контексті ринкових умов господарювання. Науковий вісник Херсонського Державного університету Випуск 22. Частина 2. 2017. С. 8-12

6. Закон України Про інноваційну діяльність від 04.07.2002 №40-IV // Відомості Верховної Ради України (ВВР). 2002. - № 36. - C. 266. URL: http://zakon.rada.gov.ua. (дата звернення 27.11.2019).

7. Закон України Про спеціальний режим інноваційної діяльності технологічних парків від 16.07.1999 № 991-XIV // Відомості Верховної Ради України (ВВР). - 1999. - № 40. - Ст. 363. URL: http://zakon.rada.gov.ua. (дата звернення 27.11.2019).

8. Стратегія сталого розвитку України до2030 року та Національний план дій до 2020 року по впровадженню Стратегіï. URL: http:// www.undp.org/content/dam/ukraine. (дата звернення 27.11.2019).

9. Стратегія інноваційного розвитку України на 2010-2020 pp. в умовах глобалізаційних викликів. URL: www.pir.dp.ua/uploads/StrategizInnovRazvitiyaUkr. (дата звернення 27.11.2019).

\section{References:}

1. Avigdor G., Arkhangelskii V., Boito E. (2015). Innovatsijna polityka: Yevropejs'kyj dosvid ta rekomendatsii dlia Ukrainy [Innovation Policy: European Experience and Rec-ommendations for Ukraine]. Feniks, Kyiv, 76 p. (in Ukrainian)

2. Boshota N.V., Shyshola D.V. (2016). Zarubizhny j dosvid derzhavnogo regulyuvannya innovacijnoyi diyal ’nosti [Foreign experience of state regulation of innovation activity]. Young scientist, vol. 9, pp. 14-18. (in Ukrainian)

3. Gollyak Yu.B. (2006) Innovacijni peretvorennya ukrayins `koyi ekonomiky` v konteksti mizhnarodnoyi konkurenciyi. [Innovative transformation of the Ukrainian economy in the context of international competition]. Current problems of the economy, no. 7(61), pp. 43-55. (in Ukrainian)

4. Kasyanenko V. (2011). Zarubizhny`j dosvid upravlinnya innovacijny`m potencialom ekonomiky` ta mozhly`vosti jogo vy`kory`stannya v Ukrayini [Foreign experience in managing the innovative potential of the economy and its potential for use in Ukraine]. Marketing and management of innovations, vol. 4, pp. 200-204. (in Ukrainian)

5. Lavrynenko S.O. (2017) Teoretychni aspekty konkurentospromozhnosti silskohospodarskoi produktsii v konteksti rynkovykh umov hospodariuvannia. [Theoretical aspects of the competitiveness of agricultural products in the context of market conditions]. Kherson State University Scientific Bulletin, issue 22, part 2, pp. 8-12. (in Ukrainian)

6. Zakon Ukrayiny «Pro innovatsiynu diyal'nist'». Vidomosti Verkhovnoyi Rady Ukrayiny (VVR) (2002). [Law of Ukraine "On innovation activity" Bulletin of the Verkhovna Rada of Ukraine (BBR)]. Verkhovna Rada of Ukraine, no. 36, pp. 266.

7. Zakon Ukrayiny «Pro spetsial'nyy rezhym innovatsiynoyi diyal'nosti tekhnolohichnykh parkiv». Vidomosti Verkhovnoyi Rady Ukrayiny (VVR) (1999). [Law of Ukraine "On Special Regime of Innovative Activity of Technology Parks" (BBR)]. Bulletin of the Verkhovna Rada of Ukraine, no. 40, pp. 363.

8. Ukraine's Sustainable Development Strategy to 2020 and National Action Plan to 2020 for the implementation of the Strategy (2017). [Stratehiya staloho rozvytku Ukrayiny do2020 roku ta Natsional'nyy plan diy do 2020 roku po vprovadzhennyu Stratehiyi]. Available at: http:// www.undp.org/content/dam/ukraine. (accessed 27 November 2019).

9. Stratehiya innovatsiynoho rozvytku Ukrayiny na 2010-2020 rr. v umovakh hlobalizatsiynykh vyklykiv (2010). [Strategy of innovative development of Ukraine for 2010-2020 in the conditions of globalization challenges]. Available at: www.pir.dp.ua/uploads/StrategizInnovRazvitiyaUkr. (accessed 27 November 2019).

\section{ЗАРУБЕЖНЫЙ ОПЫТ УПРАВЛЕНИЯ ИННОВАЦИОННЫМ ПОТЕНЦИАЛОМ ЭКОНОМИКИ}

В статье рассмотрены и проанализированы теоретические аспекты инновационной политики промышленно развитых стран. На их примере проанализирован зарубежный опыт государственного регулирования инновационной деятельности, освещены наиболее действеннье инструменты стимулирования инновационной деятельности за рубежом, обобщен рейтинг стран мира по финансированию НИОКР и по индексу глобального экономического развития. Определены особенности реализации инновационной политики стран. Выяснено, что не существует единого универсального инструмента стимулирования экономики, так как каждая страна имеет свои собственные методы управления. Обоснована иелесообразность использования инструментов в условиях украинской экономики для стимулирования инновационной деятельности предприятий, организаций и учреждений. Среди главньхх факторов восприимчивости к нововведениям выделяется инновационный потенцииал организаций или предприятий.

Ключевые слова: инновационная деятельность, инновационная политика, инновационный потенцииал, глобализащия экономики, инноваџионные структуры, инноваџионные процессы.

\section{FOREIGN EXPERIENCE OF MANAGEMENT OF INNOVATIVE POTENTIAL OF ECONOMY}

In the world economic space is complex with its nature transition of industrial technological device of industrial, in which dominates the crux of the destructive forces of development are taken by itself high technology, informatization and economics knowledge. Taking into account the global trends, the Government of Ukraine has set a goal to transform all 
the spectrum of economic opportunities and relations of the country in accordance with the chosen course of innovation development. Naturally, in relation to such a turn, the event is economic science has been insufficiently prepared, and there is today a certain gap between the practice of accelerated changes in the scientific provision of these processes. For the first time, it involves developing a strategy and a mechanism for developing the economy of the country and identifying the possibilities for realizing its innovative potential. We will show a definite question on the experience of industrialized countries, some aspects of which, in the mind of the author, may have used in Ukraine. The article generalizes and analyses the foreign experience of state regulation of innovation activity on the example of developed countries of the world. The world ranking for $R \& D$ financing and the index of global economic development are analyzed. Features of implementation of innovation policy in different countries are determined. We found that there are no universal incentive tools; each country uses its own methods. The expediency of using separate instruments in the conditions of the Ukrainian economy is grounded in order to stimulate the innovation activity of enterprises and organizations. The most effective methods of state regulation of innovation activity that can be applied in Ukraine are demonstrated. Paying tribute to the experience of domestic and foreign economists, carried out in the field of theory and methodology of innovative development of the economy and the construction of the financial security system, it should be noted that the problem of defining the system of financing innovation has not found its final solution, which makes the topic of research relevant. Improvement requires a number of questions regarding the use of additional tools to stimulate the implementation of innovative developments.

Key words: innovation, innovation policy, innovation potential, globalization of the economy, innovative structures, innovation processes. 